\title{
PENGARUH EKSTRAK DAUN PEPAYA (CARICA PAPAYA, LINN.) TERHADAP PENURUNAN INDEKS GINGIVITIS PADA PEMAKAI ALAT ORTODONTIK CEKAT
}

\author{
Hafid Nur Arzanudin ${ }^{\star}$, Arlina Nurhapsari ${ }^{* *}$, Aning Susilowati**
}

Keywords:

Gingivitis index, Papaya leaf extract, Fixed orthodontic appliance

\begin{abstract}
Background: Gingivitis is one of the serious periodontal infection desease and if there is no precise treatment it will cause the loss of tooth. Patient with fixed orthodontic appliance will be easier to be suffered by the gingivitis because the form of the appliance that attached in such a way. The gingivitis treatment has some alternatives derived from nature and traditional medicines. One of the plants which can be used as traditional medicine is papaya leaf (carica papaya L). Purpose: This study was conducted to determine the effect of papaya leaf extract toward the decline of gingivitis index in patient with fixed orthodontic appliance. Method: The method of this research was quasi-experiment with one group pre-post test design which samples were patient with fixed orthodontic appliance. The gingivitis index was examined in the sample which contains of 30 people at before and after treatment. The index was measured by counting gingival amount score devided by the number of teeth examined. The data were analyzed by using Friedman examination with the degree of significance 0,05.Result: The result of the study shows that before the treatment $56,7 \%$ patient with fixed orthodontic appliance have mild gingivitis. And after the treatment, the number of patient with fixed orthodontic appliance with mild gingivitis increase to $93,3 \%$. The significance score based on the Friedman examination was $0,000(p<0,05)$. It means there was a meaningful differences between the group which is given papaya leaf extract at before and after the treatment. Conclusion: It can be concluded that papaya leaf extract is able to decrease the gingivitis index of patient with orthodontic appliance
\end{abstract}

\section{PENDAHULUAN}

Penyakit periodontal adalah penyakit yang menyerang pada daerah gingiva dan jaringan pendukung gigi. Penyakit ini banyak diderita hampir di seluruh dunia dan prevalensinya mencapai $50 \%$ dari jumlah populasi dewasa ${ }^{1}$. Di Indonesia, penyakit periodontal menduduki urutan kedua dari beberapa penyakit yang menjadi masalah di masyarakat ${ }^{2}$. Penyakit periodontal yang utama adalah gingivitis dan periodontitis ${ }^{3}$.

Gingivitis merupakan peradangan pada gingiva, yang menyebabkan perdarahan dengan pembengkakan, berwarna kemerahan, eksudat, perubahan kontur normal, dan ketidaknyamanan pada penderitanya. Penyebab paling umum dari gingivitis adalah kebersihan mulut yang buruk. Kebersihan mulut yang buruk memungkinkan plak menumpuk antara gingiva dan gigi. Selain itu, iritasi karena plak memperdalam celah normal (sulkus) antara gigi dan gusi, menciptakan kantong gingiva. Kantong ini mengandung bakteri yang dapat menyebabkan radang gusi dan karies akar. ${ }^{4}$.

Faktor utama penyebab penyakit periodontal, termasuk gingivitis, adalah kolonisasi mikroorganisme anaerob dalam plak subgingiva. Studi klinis telah membuktikan adanya $10-15$ spesies bakteri yang berpotensi patogen terhadap jaringan periodontal pada 
orang dewasa, di antaranya bakteri yang sering ditemukan adalah Porphyromonas gingivalis (P. gingivalis), Actinomycetemcomitans aggregatibacter (A. actinomycetemcomitans), Tannerella forsythensis ( $T$. forsythensis) dan Prevotella intermedia (P. intermedia) ${ }^{5}$.

Faktor-faktor lokal lainnya yang dapat menyebabkan gingivitis adalah maloklusi, kalkulus gigi, impaksi makanan, restorasi gigi rusak, xerostomia dan penggunaan alat ortodontik ${ }^{4}$. Pada penggunaan alat ortodontik cekat, sangat penting untuk menjaga dan meningkatkan kebersihan gigi dan mulut, mengingat alatnya yang melekat sedemikan rupa, sehingga akan memudahkan terbentuknya akumulasi plak dan bakteri pada daerah tersebut yang menyebabkan gingivitis. Bakteri dapat melekat leluasa ditempat tersembunyi pada alat-alat tersebut. Bakteri akan bertambah banyak bila penderita kurang memperhatikan kebersihan rongga mulutnya ${ }^{6}$.

Obat tradisional sekarang ini menjadi alternatif lain untuk pengobatan yang lebih murah dan berasal dari alam sekitar. Salah satu tanaman yang dapat dimanfaatkan sebagai obat tradisional adalah tanaman daun pepaya (Carica papaya L.). Daun Pepaya sering digunakan sebagai pengobatan tradisional karena tanaman ini memiliki kandungan senyawa alkaloid, saponin dan flavonoid yang memiliki efektivitas antibakteri pada daun, akar dan kulit batangnya, mengandung polifenol pada daun dan akarnya, serta mengandung saponin pada bijinya ${ }^{7}$. Menurut hasil penelitian Irsya (2013) serta Jati dan Manitis (2013), konsentrasi $40 \%$ ekstrak daun pepaya mengandung senyawa yang dapat menghambat pertumbuhan bakteri Porphyromonas gingivalis dan Actinomycetemcomitans aggregatibacter karena senyawa yang terkandung di dalam ekstrak daun pepaya dapat mengganggu keutuhan struktur dinding sel bakteri ${ }^{8,9}$.

Berdasarkan uraian di atas maka penulis tertarik untuk meneliti tentang pemberian ekstrak daun pepaya untuk menurunkan indeks gingivitis pada pemakai alat ortodontik cekat. Hasil penelitian ini diharapkan dapat digunakan oleh masyarakat, terutama dalam penggunaan obat tradisional untuk mempercepat proses penyembuhan gingivitis karena pemakaian alat ortodontik cekat.

\section{METODE PENELITIAN}

Jenis penelitian yang digunakan adalah penelitian eksperimental semu dengan rancangan one group pre-post test design. Sampel yang digunakan adalah pemakai alat ortodontik yang berusia 18-21 tahun serta menderita gingivitis dan sampel yang digunakan untuk penelitian ini sebanyak 30 orang.

Instrumen yang digunakan dalam penelitian adalah Probe WHO, Mouth mirror, Pinset. Sedangkan bahan yang digunakan dalam penelitian adalah Ekstrak daun pepaya $40 \%$.

Tahap Penelitian meliputi pemilihan sampel yang memenuhi kriteria inklusi. Penjelasan mengenai penelitian yang akan dilakukan kepada sampel dan meminta persetujuan sebagai sampel penelitian (Informed consent). Sampel yang sudah memenuhi kriteria inklusi diperiksa terlebih dahulu sulkus gingivanya dengan Probe WHO dan hitung kedalaman sulkus gingiva menggunakan indeks gingivitis sebelum diberi perlakuan. Sampel disuruh berkumur dengan larutan ekstrak daun pepaya sebanyak $10 \mathrm{ml}$ dan selama 30 detik. Sampel berkumur dengan larutan ekstrak daun pepaya setiap hari selama 10 hari, dengan rincian :

1. Pada hari pertama dilakukan pemeriksaan indeks gingivitis dan berkumur dengan larutan ekstrak daun pepaya.

2. Pada hari kelima dilakukan pemeriksaan indeks gingivitis.

3. Pada hari kesepuluh dilakukan pemeriksaan indeks gingivitis.

Uji normalitas akan diuji dengan uji Shapiro-Wilk dengan tingkat kemaknaan $\alpha \geq 0,05$. Untuk menganalisis perbedaan penurunan indeks gingiva sebelum dan sesudah pemberian ekstrak daun pepaya pada sampel akan dilakukan dengan uji Repeat Anova (uji parametik) dilanjutkan uji PostHoc jika memenuhi syarat. Jika tidak memenuhi 
syarat, maka digunakan uji alternatifnya yaitu menggunakan uji Friedman (uji nonparametik).

\section{HASIL PENELITIAN}

Hasil dari penelitian terdapat pada tabel $1-5$.

Tabel 1. Statistik Deskriptif

\begin{tabular}{lccc}
\hline & $\mathrm{N}$ & Rata-rata & Simpang Baku \\
\hline Sebelum & 30 & 1,1823 &, 70029 \\
Sesudah & 30 &, 3167 &, 32764 \\
\hline
\end{tabular}

Tabel 2. Tingkat Keparahan Gingivitis Sebelum Perlakuan

\begin{tabular}{|c|c|c|}
\hline Tingkat Keparahan & Frekuensi & Prosentase (\%) \\
\hline Ringan & 17 & 56,7 \\
\hline Sedang & 9 & 30,0 \\
\hline Parah & 4 & 13,3 \\
\hline Total & 30 & 100,0 \\
\hline
\end{tabular}

Tabel 3. Tingkat Keparahan Gingivitis Sesudah Diberi Perlakuan

\begin{tabular}{|c|c|c|}
\hline Tingkat Keparahan & Frekuensi & Prosentase (\%) \\
\hline Ringan & 28 & 93,3 \\
\hline Sedang & 2 & 6,7 \\
\hline Parah & 0 & 0 \\
\hline Total & 30 & 100,0 \\
\hline
\end{tabular}

Tabel 4. Hasil Uji Friedman

Ranks

\begin{tabular}{lr}
\hline & Mean Rank \\
\hline Hari Ke 0 & 3,00 \\
Hari Ke 5 & 1,88 \\
Hari Ke 10 & 1,12 \\
\hline
\end{tabular}

Tabel 5. Tes Statistik Uji Friedman

Test Statistics ${ }^{\mathrm{a}}$

\begin{tabular}{lr}
\hline N & 30 \\
Chi-Square & 57,150 \\
Df & 2 \\
Asymp. Sig. &, 000 \\
\hline
\end{tabular}

a. Friedman Test 
Penelitian ini menggunakan uji ShapiroWilk untuk mengetahui normalitas data karena sampel yang digunakan adalah kurang dari 50 sampel.

Karakteristik data yang tidak memenuhi syarat normalitas menunjukkan bahwa uji yang digunakan untuk mengetahui perbedaan secara nyata adalah dengan uji non parametrik yaitu uji Friedman. Tabel 4. menunjukkan semua indeks gingivitis sesudah diberi ekstrak daun pepaya lebih kecil dibandingkan indeks gingivitis sebelum diberi ekstrak daun pepaya.

Nilai Asymp. Sig pada tabel 5. menunjukkan hasil sebesar 0,000. Nilai signifikansi ini lebih kecil dari level of significant (a) sebesar 0,05. Berdasarkan hasil ini dapat diartikan, terdapat perbedaan bermakna pada kelompok sebelum diberi ekstrak daun pepaya dengan kelompok sesudah diberi ekstrak daun pepaya. Hal ini berarti bahwa terdapat pengaruh pemberian ekstrak daun pepaya terhadap penurunan indeks gingivitis pada pemakai alat ortodontik cekat.

\section{DISKUSI}

Hasil penelitian menunjukan bahwa sebagian besar responden adalah perempuan. Penurunan indeks gingivitis pada perempuan lebih besar dibandingkan dengan penurunan indeks gingivitis pada laki - laki.

Berdasarkan kelompok usia, sebagian besar responden berusia 20 tahun. Terdapat perbedaan penurunan indeks gingivitis antar kelompok usia, penurunan indeks gingivitis terbesar terjadi pada kelompok usia 19 tahun, dimana pada umur tersebut susunan gigi dan kekebalan tubuh sudah mencapai kompleksitasnya. Usia juga mempengaruhi jenis makanan dan kemampuan pertahanan tubuh terhadap benda asing, salah satunya bakteri mulut, sehingga dengan adanya perubahan usia juga terjadi perubahan lingkungan mulut ${ }^{10}$.

Penelitian yang dilakukan mendapatkan hasil indeks gingivitis sesudah diberi ekstrak daun pepaya menurun dibandingkan dengan indeks gingivitis sebelum diberi ekstrak daun pepaya. Pada penderita gingivitis parah sudah tidak ditemukan penderitanya dan jumlah penderita gingivitis sedang menurun prosentasenya menjadi tingkat keparahan ringan yang berarti terdapat penurunan tingkat keparahan.

Nilai rata - rata indeks gingivitis sesudah diberi ekstrak daun pepaya mengalami penurunan dibandingkan sebelum diberi ekstrak daun pepaya. Hasil uji Friedman mendapatkan nilai signifikansi lebih kecil dari level of significance 0,05 yang berarti terdapat perbedaan bermakna rata - rata indeks gingivitis sebelum diberi ekstrak daun pepaya dengan sesudah diberi ekstrak daun papaya pada hari ke 5 maupun pada hari ke 10 .

Hasil uji statistik menunjukkan perbedaan antar kelompok perlakuan yaitu antara hari ke 0 , hari ke 5 serta hari ke 10 . Perlakuan selama rentang waktu 10 hari mendapatkan hasil yang lebih baik dibandingkan rentang waktu 5 hari. Semakin lama pemakaian ekstrak daun pepaya semakin efektif untuk menghilangkan gingivitis. Hal ini sesuai dengan teori fase penyembuhan luka dimana pada fase inflamasi terjadi pada hari ke $0-5$, fase proliferasi terjadi pada hari ke $3-14$, dan fase maturasi terjadi pada hari ke 7 - 1 tahun ${ }^{11}$.

Konsentrasi $40 \%$ ekstrak daun pepaya mengandung senyawa yang dapat menghambat pertumbuhan bakteri Porphyromonas gingivalis dan Actinomycetemcomitans aggregatibacter karena senyawa yang terkandung di dalam ekstrak daun pepaya dapat mengganggu keutuhan struktur dinding sel bakteri ${ }^{8,9}$. Daun pepaya mengandung senyawa kimia alkaloid, flavanoid dan saponin yang mempunyai sifat antibakteri. Senyawa Alkaloid yang terkandung di dalam ekstrak pepaya memiliki kemampuan sebagai antibakteri dengan cara menggangu komponen penyusun peptidoglikan pada sel bakteri ${ }^{9}$. Gugus basa yang terdapat di senyawa alkaloid jika mengalami kontak dengan bakteri akan bereaksi dengan senyawa asam amino yang menyusun dinding sel bakteri dan DNA bakteri yang merupakan pusat pengaturan segala kegiatan sel. Reaksi senyawa asam amino dengan bakteri mengakibatkan terjadinya perubahan struktur dan susunan asam amino. Perubahan susunan asam amino akan merubah 
susunan rantai DNA pada inti sel yang semula mempunyai susunan asam dan basa yang saling berpasangan. Perubahan susunan asam amino mengakibatkan perubahan keseimbangan genetik pada asam DNA, sehigga DNA bakteri akan mengalami kerusakan. Kerusakan sel pada bakteri lama kelamaan akan membuat sel bakteri tidak mampu melakukan metabolisme sehingga menjadi inaktif atau lisis ${ }^{12}$.

Senyawa antibakteri lainnya yang terdapat pada daun pepaya yaitu flavonoid. Mekanisme kerja senyawa flavonoid sebagai antibakteri adalah menghambat sistem DNA dan RNA dari bakteri, menghambat membran sitoplasma yang mengakibatkan hilangnya sistem pertahanan sel bakteri sehingga terjadi kebocoran bahan intraseluler, dan mengganggu metabolisme energi bakteri berupa oksigen yang mengganggu proses penyerapan beberapa metabolit ${ }^{13}$. Flavonoid mampu melepaskan energi tranduksi terhadap membran sitoplasma bakteri serta menghambat motilitas bakteri. Mekanisme antibakteri flavonoid adalah dengan mempengaruhi fungsi sel yaitu mendenaturasi protein sel yang terdapat pada dinding sel dan membran sel ${ }^{14}$.

Disamping alkaloid dan flavonoid, daun pepaya juga mengandung senyawa saponin yang mempunyai aktivitas antibakteri. Saponin merupakan zat aktif pada tumbuhan yang dapat meningkatkan permeabilitas membran sehingga terjadi hemolisis sel, apabila saponin berinteraksi dengan sel bakteri, maka bakteri tersebut akan pecah atau lisis ${ }^{15}$.

Berdasarkan hasil penelitian didapatkan hasil lama waktu pemakaian alat ortodontik cekat tidak terlalu berbeda nilai penurunan indeks gingivitisnya.

\section{KESIMPULAN}

Terdapat pengaruh pemberian ekstrak daun pepaya terhadap penurunan indeks gingivitis pada pemakai alat ortodontik cekat.

\section{DAFTAR PUSTAKA}

1. Carranza, F.A. Glickman's Clinical Periodontology (10th ed). Philadelphia: WB. Saunders Company, hal: 118, 355-360 (2006).

2. Wahyukundari, M.A. Perbedaan Kadar Matrix Metalloproteinase-8 Setelah Scaling dan Pemberian Tetrasiklin pada Penderita Periodontitis Kronis. Jurnal PDGI Vol 58(1): 1-6 (2009).

3. Rose, L.F., Genco, R.J., Cohen, J.W., Mealey, B.L. Periodontal Medicine. B.C. Decker Inc: London (2000).

4. Ubertalli, J.T. Gingivitis. http://www.merckmanuals. com/professional/dental_disorders/periodontal_ disorders/gingivitis. $h t m l$ ? $\overline{\mathrm{t}}=$ gingivitis \&sc=\&alt=sh (2012). Diunduh 2 Maret 2014

5. Igic, M., Kesic, L., Lekovic, V., Apostolovic, M., Mihailovic, D., Kostadinovic, L., Milasin, J. Chronic Gingivitis: The Prevalence of Periodontopathogens and Therapy Efficiency. Eur J Clin Microbiol Infect Dis 31: 1911-1915 (2012).

6. Mathewson, R.J. \& Primosch, R.E. Fundamentals of Pediatric Dentistry (3rd ed). Chicago: Quintessence Books, hal: 89-90 (1995).

7. Departemen Kesehatan dan Kesejahteraan Sosial RI. Inventaris Tanaman Obat Indonesia (I). Jakarta (2000).

8. Irsya, W. F. Pengaruh Efek Ekstrak Daun dan Biji Pepaya (Carica papaya) Terhadap Actinobacillus Actinomicetemcomitans (Uji Coba Secara In Vitro). Skripsi. Semarang. Jurusan Kedokteran Gigi. Fakultas Kedokteran Gigi. Universitas Islam Sultan Agung Semarang (2013).

9. Jati, R.I., Manitis, A.V. Efektivitas Antibakteri Ekstrak Daun Pepaya (Carica papaya) terhadap Pertumbuhan Porphyromonas gingivalis. BIMKGI Vol.1 (2) edisi: Januari-Juni (2013).

10. Nareswari, A. Perbedaan Efektivitas Obat Kumur Chlorhexidine Tanpa Alkohol Dibandingkan dengan Chlorhexidine Beralkohol Dalam Menurunkan Kuantitas Koloni Bakteri Rongga Mulut. Skripsi. Surakarta. Jurusan Kedokteran. Fakultas Kedokteran. Universitas Sebelas Maret Surakarta (2010).

11. Mast, A.B. Normal Wound Healing. In: Anchauer BM, Eriksson E, eds. Plastic Surgery, Indications, Operations and Outcomes. Mosby: Mosby Inc, hal: 37-53 (2000).

12. Saputra, T., Suryani, L. Aktivitas Antimikroba Infusa Buah Asam Jawa (Tamarindus indica Linn) Terhadap Berbagai Mikroba Patogen. Laporan Penelitian Fakultas Kedokteran, Universitas Muhammadiyah Yogyakarta, 8 (9) (2012).

13. Cushnie, T.P.T., Lamb, A.J. Antimicrobial Activity of Flavonoids. International Journal of Antimicrobial, 343-356 (2005). 
14. Isnarianti, R., Wahyudi, I.A., Puspita, R.M. Muntingia calabura L Leaves Extract Inhibits Glucosyltransferase Activity of Streptococcus mutans. Journal of Dentistry Indonesia, Vol. 20 (3), 59- 63 (2013).

15. Poeloengan, M., Praptiwi. Uji Aktivitas Antibakteri Ekstrak Kulit Buah Manggis (Garcinia mangostana Linn). Media Litbang Kesehatan Vol. XX (2) (2010). 